\title{
INDIRECTLY DIRECTORS: DUTIES OWED BELOW THE BOARD
}

\author{
Fran Barber
}

In 2012, the High Court of Australia considered the scope of the term "officer" in a case concerning the breach of a statutory duty by a company secretary and general counsel. The equivalent duties under the New Zealand Companies Act 1993 are owed by an ostensibly narrower class. In considering how New Zealand law would apply to the same situation, this article discusses the extent to which directors' duties are, or should be, owed by those below directorship level. It concludes that an expansive interpretation of the "director" definition is unnecessary and undesirable, and that explicitly extending the definition to encompass certain senior managers would create uncertainties for courts and corporate leaders.

\section{INTRODUCTION}

In the wake of the 2007-2008 global financial crisis, the need to foster renewed investor confidence has been central to law reform. The creation of the Financial Markets Authority (FMA) in 2011 heralded a new era of public enforcement in this sphere. As at June 2013, 32 finance company directors had been convicted pursuant to FMA prosecutions. ${ }^{1}$

Moreover, the nature and enforcement of directors' duties is currently undergoing statutory change - the Companies and Limited Partnerships Amendment Bill is expected to be passed soon, ${ }^{2}$ and the Financial Markets Conduct Act 2013 will be implemented in phases throughout 2014. With directors' duties in a state of flux, it is an opportune time to discuss the fundamental duties contained within the Companies Act 1993 (Companies Act). In its 2010 review of securities law, the Ministry of Economic Development declined to consider the classes of persons to whom these statutory

* Article submitted as part of the LLB(Hons) programme at Victoria University of Wellington. I am grateful to Victoria Stace for her invaluable guidance and supervision in writing this article.

1 Financial Markets Authority Investigations and Enforcement Report 2013 (June 2013) at 22.

2 Companies and Limited Partnerships Amendment Bill 2011 (344-2). 
duties apply. ${ }^{3}$ Yet, in the midst of efforts to harmonise New Zealand's company and securities law with its trans-Tasman equivalent, this is a key area of divergence. As such, it warrants discussion.

What may be described as the "core" directors' duties are owed by both directors and other officers under the Australian Corporations Act 2001 (Cth) (Corporations Act), whereas in New Zealand duties are only owed by directors. In mid-2012, the High Court of Australia explored the term "officer", finding the company secretary and general counsel of James Hardie Industries Ltd, Peter Shafron, liable for breaching his duty of care and diligence. ${ }^{4}$

Through the lens of Shafron v Australia Securities and Investments Commission (Shafron v $A S I C$ ), this article will discuss whether Shafron would have been liable had the same circumstances arisen in New Zealand. Ultimately, it will assert that amending the scope of these statutory duties in New Zealand to include those below board level would create uncertainty without any real benefit.

Part II and Part III of this article consider the statutory duties owed by directors under New Zealand and Australian company law. Part IV analyses Shafron $v$ ASIC, and Part V, the scope of s 126 of the Companies Act and the term "director". The consequences of breach are dealt with in Part VI, after which Part VII investigates whether New Zealand's directors' duties should extend to somebody in Shafron's position. Finally, Part VIII offers a conclusion.

\section{STATUTORY DUTIES OWED BY DIRECTORS UNDER NEW ZEALAND COMPANY LAW}

The Companies Act provides a foundational management structure for New Zealand companies. Directors are vested with all powers necessary to manage the company ${ }^{5}$ and the shareholders are at least conceptually - removed from the picture. ${ }^{6}$ As is necessary, the board may delegate any of its powers other than those listed in sch $2 .{ }^{7}$ While these provisions may be altered by the company's constitution, in all circumstances those at the apex of the company will be directors (as that term is extended by s 126) and subject to certain duties. The Companies Act is silent regarding duties owed below board level. Unlike its predecessor, it does not refer to "officers", nor devolve any powers to roles such as the "company secretary".

3 Ministry of Economic Development Review of Securities Law Discussion Paper (June 2010) at 183.

4 Shafron $v$ Australian Securities and Investments Commission [2012] HCA 18, (2012) 286 ALR 612 [Shafron $v$ ASIC]

5 Section 128

6 In closely held companies, it is likely that the principals will be both shareholders and directors.

7 Section 130 
Legal regulation, through the imposition and enforcement of duties, is central to defining and enforcing expectations of directors. In addition, past decades have seen the proliferation of "best practice codes" in different jurisdictions. Many factors form "proper corporate governance", for example the inclusion of non-executive directors on the board, having separate chairperson and chief executive officer roles, and efficient auditing and disclosure practices. ${ }^{8}$

The Companies Act prescribes certain fundamental duties owed by directors to the company. Heath $\mathrm{J}$ in Benton $v$ Priore regarded the provisions as simply a "restatement of basic duties in an endeavour to promote accessibility to the law". ${ }^{9}$ The duties parallel those owed in equity and common law. ${ }^{10}$ The statutory equivalent to the fiduciary duties of loyalty and good faith is found in s 131, whereby directors must act in good faith and in the best interests of the company. Section 133 requires directors to exercise powers for a proper purpose, and s 134 prohibits directors from contravening the Companies Act or the company's constitution. Sections 139 to 149 prevent directors from engaging in self-interested transactions. The common law duty of care, diligence and skill is contained in s 137. Relevant when a company encounters financial difficulty, ss 135 and 136 contain duties aimed at protecting creditors (while still being owed to the company).

\section{STATUTORY DUTIES OWED BY OFFICERS UNDER AUSTRALIAN COMPANY LAW}

Australia's Corporations Act contains substantively similar duties to the New Zealand Companies Act and, as in New Zealand, the common law and equitable duties and remedies remain relevant. ${ }^{11}$ Under s 181, officers must act in good faith in the best interests of the corporation and for a proper purpose. Section 180 states that officers must exercise the degree of care and diligence that a reasonable person would exercise in the same circumstances. The duty of care and diligence will be met if the director is exercising "business judgment" - an exception not explicit in the Companies Act. If made in good faith for a reasonable purpose, without material interest in the subject matter, business decisions will not be justiciable. ${ }^{12}$

8 See RP Austin, HAJ Ford and IM Ramsay Company Directors: Principles of Law and Corporate Governance (LexisNexis Butterworths, Chatswood (NSW), 2005) at [1.6].

9 Benton v Priore [2003] 1 NZLR 564 (HC) at [46].

10 John Farrar Corporate Governance: Theories, Principles and Practice (3rd ed, Oxford University Press, Melbourne, 2008) at 108-110.

11 Section 185.

12 Section $180(2)$. 
Both officers and other employees of the corporation owe duties not to improperly use their position, ${ }^{13}$ or information gained due to their position, ${ }^{14}$ to gain an advantage for themselves or others. Directors (but not officers) also owe duties to prevent insolvent trading. ${ }^{15}$

With the exception of the insolvent trading provision, duties are owed by "officers" - ostensibly a much wider class than in New Zealand. Section 9 of the Corporations Act provides:

"officer" of a corporation means:

(a) a director or secretary of the corporation; ${ }^{16}$ or

(b) a person:

(i) who makes, or participates in making, decisions that affect the whole, or a substantial part, of the business of the corporation; or

(ii) who has the capacity to affect significantly the corporation's financial standing; or

(iii) in accordance with whose instructions or wishes the directors of the corporation are accustomed to act (excluding advice given by the person in the proper performance of functions attaching to the person's professional capacity or their business relationship with the directors of the corporation)[.]

\section{SHAFRON v ASIC}

In 2010, the High Court of Australia explored the boundaries of the "officer" definition in determining whether a senior executive owed a duty of care under s 180(1) of the Corporations Act. Peter Shafron was the company secretary and general counsel of James Hardie Industries Ltd (JHIL) and one of 10 defendants against whom the Australian Securities and Investments Commission (ASIC) issued proceedings concerning the company's 2001 restructuring.

JHIL was the publicly listed holding company for the James Hardie Group. Two subsidiaries had manufactured asbestos products and were liable for extensive personal injury claims, with more expected. Finding a solution to this "asbestos litigation poison pill" culminated in a meeting on 15 February 2001, where the board approved a separation proposal. ${ }^{17}$ Crafted by several senior

13 Section 182.

14 Section 183.

15 Section 588G.

16 "Director" is defined in s 9 to include de jure, de facto and shadow directors.

17 Morley v Australian Securities and Investments Commission [2010] NSWCA 331, (2010) 247 FLR 140 [Morley $v$ ASIC] at [55]. 
executives including Shafron, liability would be effectively contained within a Medical Research and Compensation Foundation, which would manage claims and research asbestos related diseases. JHIL's shares in the subsidiaries, along with AUD3,000,000, would be vested in the Foundation. A Deed of Covenant and Indemnity (DOCI) would be entered, whereby the subsidiaries indemnified the holding company against any asbestos-related liabilities. In return, JHIL would contribute annually to the Foundation until 2042. James Hardie Industries NV would be incorporated in the Netherlands to replace JHIL.

The Foundation's funding was severely inadequate. In holding JHIL's management accountable, ASIC's claim centred on the February board meeting. There, the board approved a draft media release to the Australian Securities Exchange (ASX) advising of the restructuring. This was found to be materially similar to the final announcement released the following day, which asserted that "[t]he Foundation has sufficient funds to meet all legitimate compensation claims anticipated". ${ }^{18}$ This proved false. Furthermore, JHIL failed to disclose the DOCI to the ASX as required by the ASX Listing Rules and s 1001A of the Corporations Act.

Shafron was, according to the High Court, either the second or third most senior executive in the company. He had extensive involvement in the separation process, formulating various proposals and presenting them to the board. On behalf of JHIL, it was Shafron who retained the actuaries involved in the cash flow modelling which formed the basis of the Foundation's funding. ${ }^{19}$

At first instance, the Court issued several declarations of contravention. In breach of s 180(1), Shafron was found to have failed to advise:

(a) the board that the draft announcement was misleading and "expressed in too emphatic terms concerning the adequacy of ... funding"; ${ }^{20}$

(b) the board that the cash flow model reviews only concerned "logical soundness and technical correctness" and the external advisers had been instructed not to consider certain fundamental assumptions; ${ }^{21}$ and

18 Australian Securities and Investments Commission v Hellicar [2012] HCA 17, (2012) 286 ALR 501 [ASIC v Hellicar] at [17].

19 Shafron $v$ ASIC, above n 4, at [28].

20 Australian Securities and Investments Commission v Macdonald (No 11) [2009] NSWSC 287, (2009) 230 FLR 1 at [1271].

21 At [1272] 
(c) the board or the Chief Executive Officer of the requirement to disclose the DOCI information. He knew or ought to have known that the failure to do so risked contravening JHIL's legal obligations and could harm its reputation. ${ }^{22}$

On appeal, the Court of Appeal set aside the first two contraventions but added another: Shafron's failure to advise the board that the "best estimate" of asbestos liabilities (central to the proposed funding) "had not taken into account superimposed inflation, and a prudent estimate would have". ${ }^{23}$

\section{A High Court}

Shafron appealed the DOCI contravention and the superimposed inflation contravention to the High Court of Australia. He argued that his participation in decision-making did not meet the threshold to make him an officer as defined in s 9(b)(i)-(ii) of the Corporations Act. ${ }^{24}$

\section{Dual role}

Shafron submitted that his omissions should not constitute a breach of s 180(1), as he was not acting as company secretary at the relevant time but in his general counsel capacity. ${ }^{25}$ ASIC countered that Shafron was an officer as he was a company secretary (expressly included in s 9), and his general counsel role was relevant to what a reasonable person would do if they had his "responsibilities within the corporation" as per s 180(1).

The High Court held that the scope of an office is a question of fact. One cannot assume that two offices bearing the same title are identical, thus the duties of JHIL's other company secretary could not be indicative of the scope of Shafron's role. ${ }^{26}$ Shafron had two roles that were not mutually exclusive. ${ }^{27}$ Therefore, his duties extended to fulfilling his actual role as company secretary and general counsel. ${ }^{28}$

22 At [1277].

23 Morley v ASIC, above n 17, at [1156]

24 Shafron v ASIC, above n 4, at [22].

25 At [8].

26 At [41].

27 At [11].

28 At [16]. 
Citing the prior judgment, the High Court stated: ${ }^{29}$

A company secretary with legal background would be expected to raise issues such as potential misleading statements ... and disclosure obligations ... with the board. Ordinarily it might not be the same with respect to a matter such as the JHIL cash flow modelling, which required particular expertise. But Mr Shafron had a quite close involvement with the cash flow modelling, and raising the limitations of the cash flow model is by no means a legal matter for the attention of a general counsel; the involvement, and raising the limitations, in our view fell within Mr Shafron's responsibilities as company secretary.

\section{Participation in Making Decisions}

Shafron also submitted that he was not an officer as he merely "provided information and advice to the board to assist it in its decision making". ${ }^{30}$ While he accepted that the definition was not dependent upon "ultimate control", he argued that he had no role in actually making the decision. ${ }^{31}$ The Court expressed four considerations in interpreting what constitutes "participation in making decisions":

(a) The inquiry concerns the person's role in the corporation, not just their role regarding the alleged breach. ${ }^{32}$

(b) Where breaches are omissions to provide advice, the person's actions on other occasions will be relevant in determining what a reasonable person would do. ${ }^{33}$

(c) "Officers" do not need to be performing a role analogous to "directors". ${ }^{34}$

(d) The term "participation" "directs attention to the role that a person has in the ultimate act of making a decision, even if that final act is undertaken by some other person or persons". It is a "question of fact and degree". 35

Shafron was found to have participated in making decisions of sufficient importance to engage the s 9(b)(i) definition in the Corporations Act: ${ }^{36}$

29 Morley v ASIC, above n 17, at [926] cited in Shafron $v$ ASIC, above $\mathrm{n} 4$, at [20].

30 Shafron $v$ ASIC, above n 4, at [22].

31 At [22].

32 At [23].

33 At [24].

34 At [25].

35 At [26]. 
That what he did can be described as proffering advice or providing information for the board's consideration is not an end to the relevant inquiry. The conclusion that he participated in making the decision depends not only upon what he did but also upon identifying the relationship between his actions and the decision to adopt the proposal as "participation" in making the decision. ... Shafron was one of three executives who shaped and developed the proposal through its successive variants; ... he was ... part of the "promotion of the separation proposal to the board", a board that did not itself decide what elements would go to make up any of the several proposals it considered and was, as ASIC submitted, "reactive" rather than "proactive" in the formulation of the proposals.

The High Court made three final declarations of contravention. Approving the Court of Appeal's declaration regarding superimposed inflation, ${ }^{37}$ it restored the first Court's finding as to the misleading draft announcement, ${ }^{38}$ and retained the initial contravention regarding DOCI disclosure. $^{39}$

This case clarifies the threshold at which a senior executive in Australia will be considered an officer and subsequently exposed to public prosecution by ASIC. Shafron's penalty was significant seven years disqualification from management and an AUD75,000 pecuniary penalty. This was more than double that given to the majority of JHIL directors. ${ }^{40}$

\section{$V$ SECTION 126 AND THE SCOPE OF "DIRECTOR"}

Under New Zealand law, core duties are only owed by "directors". However, that term is given an extended meaning under s 126. The definition does not purport to be exhaustive, but includes four classes: de jure directors, de facto directors, shadow directors and delegated directors. Duties are imposed on all four classes. ${ }^{41}$ While somebody in Shafron's position would likely not be a de facto or shadow director, he could arguably be found to be a delegated director. This part will explore the scope of these classes.

The following are "directors" under s 126.

36 At [31].

37 At [34]-[36].

38 ASIC v Hellicar, above n 18, at [315].

39 At [33].

40 Gillfillan v Australian Securities and Investments Commission [2012] NSWCA 370 [Gillfillan v ASIC] at [363].

41 Note, a person who is a "director" under s 126(1)(d) because they provide directions or instructions to a deemed director will not be subject to the core duties. 


\section{A De Jure Directors}

These are validly appointed as per ss 150-159, and will be directors regardless of official title.

\section{B De Facto Directors}

A person acting as a director without being appointed may be deemed a de facto director. The role of a de facto director on the board will be legally ineffectual, yet they may still have a significant influence on the workings of the board and the company. There is some uncertainty whether de facto directors properly fall within s 126(1)(a), but a leading New Zealand judgment suggests that they do. ${ }^{42}$ The Court of Appeal included de facto directors in s 126(1)(a) in Clark $v$ Libra Developments Ltd, describing them as those "held out as a director by the company" who "undertook functions in relation to the company which could properly be discharged only by a director". ${ }^{43}$

The separation of functions exercisable only by directors from those of senior management may be difficult. Nevertheless, Shafron was clearly not purporting to act as a director, but as a senior executive. He was liable for advising the board, not for acting as part of it.

\section{Shadow Directors}

Section 126(1)(b)(i) states that "a person in accordance with whose directions or instructions" a s 126(1)(a) director "may be required or is accustomed to act" will be considered to be a director.

Arguably, if a wide construction of "directions or instructions" were adopted, it is conceivable that a senior employee who advises the board in making decisions may fall within this definition. Section 126(4) protects those acting "only in a professional capacity" from becoming deemed directors. However, instructions outside the director's profession might go beyond this exception.

Re Hydrodam (Corby) Ltd held that shadow directorship arises when there is "a pattern of behaviour in which the board did not exercise any discretion or judgment of its own, but acted in accordance with the directions of others". ${ }^{44}$ Directors are merely puppets. More recently, the English Court of Appeal in Secretary of State for Trade and Industry $v$ Deverell (Deverell) found senior managers liable as shadow directors despite giving no compulsory instructions to the board. ${ }^{45}$ Morritt $\mathrm{J}$ stated that while legislation seeks to identify those with "real influence" within the

42 Peter Watts Directors' Powers and Duties (LexisNexis, Wellington, 2009) at 8.

43 Clark v Libra Developments [2007] 2 NZLR 709 (CA) at [176] citing Re Hydrodam (Corby) Ltd [1994] 2 BCLC 180 (Ch) at 183. This approach was recently applied in Delegat v Norman [2013] NZHC 3485.

44 Re Hydrodam (Corby) Ltd, above n 43, at 183.

45 Secretary of State for Trade and Industry v Deverell [2001] Ch 340 (CA). 
company, such influence need not be exercised "over the whole field of its corporate activities". ${ }^{46}$ Non-professional advice may be sufficient, without the board "surrender[ing] their respective discretions". ${ }^{47}$ This supports the notion that a senior executive without final decision-making capacity could nevertheless be deemed a shadow director.

Deverell has yet to be discussed in detail in New Zealand and has been subject to numerous critiques, ${ }^{48}$ but has been cited as law by the English High Court as recently as September $2013 .{ }^{49}$ In the writer's opinion, "shadow directorship" is conceptually distinct from being a company "officer" (notwithstanding the confusing situation in the Corporations Act where the definition of a shadow director is included in both the "officer" and "director" definitions). Directors are assumed to be at the company's helm; "officer" denotes a lower level of authority. Deverell obscures this, as directors retain their final judgement, but their subordinate advisers may be deemed to be directors alongside them. The rationale for penalising shadow directors is that they are controlling the exercise of directors' powers. However, mere advisers cannot be responsible for a decision if they did not make it. $^{50}$ As Noonan and Watson stress, "advice that is followed because it is good advice is not instruction or direction". 51

Even with the Deverell precedent, somebody in Shafron's position is unlikely to be held liable. While he certainly influenced the final decision, the board did not act on his advice as such. Indeed, they rejected the separation proposal from the preceding board meeting. ${ }^{52}$ While this situation could conceivably fit within the notion of "advice", it would be a strained and unsatisfactory construction. Shafron was a senior executive, not a "shadow director".

46 At [35].

47 At [35].

48 See Chris Noonan and Susan Watson "The Nature of Shadow Directorship: Ad Hoc Statutory Intervention or Company Law Principle?" [2006] JBL 763 at 773. Noonan and Watson note that the Secretary of State was declined leave to argue that the defendants were de facto directors, which was likely to have been found on the facts. For them to be liable, it was necessary for the court to apply the shadow director provision. See also Matthew Barber "Shadow directors: compulsion vs advice" [2011] NZLJ 85.

49 Vivendi SA Centenary Holdings III Limited v Richard \& Ors [2013] EWHC 3006 (Ch)

50 Barber, above n 48, at 87 .

51 Noonan and Watson, above n 48, at 777.

52 Shafron $v$ ASIC, above $\mathrm{n} 4$, at [29]. 


\section{Delegated Directors}

Section 126(1)(c) bestows duties upon:

... a person to whom a power or duty of the board has been directly delegated by the board with that person's consent or acquiescence, or who exercises the power or duty with the consent or acquiescence of the board[.]

Fatupaito $v$ Bates is the sole case involving a delegated director under s 126(1)(c), but provides little aid to the section's application in other circumstances. ${ }^{53}$ Misunderstanding the nature of a receivership, the company's director requested that Bates, an accountant and business adviser, act as receiver. The director passed all of his powers within the company to Bates. If he had properly been appointed as receiver, Bates would have been protected by his professional status. ${ }^{54}$ However, in the circumstances he was acting as a delegated director and could therefore be found liable for breach of the reckless trading provision in s 135.

Had s 126(1)(c) not been raised, Bates would have been a de facto director, as he controlled the business at the relevant time. ${ }^{55}$ Where there is a circumscribed delegation of powers however, it is unclear how far this provision might extend. Depending on how a "power or duty of the board" is defined, this may encompass a range of senior employees.

The Companies Act vests in the board "all the powers necessary for managing, and for directing and supervising the management of, the business and affairs of the company." ${ }^{6}$ It would seem, therefore, that any act of management delegated by the board would bring that delegate within $\mathrm{s}$ 126(1)(c). In all but the smallest companies, delegation is necessary for the day-to-day operation of the business. Which delegates then, could be deemed directors?

Some murkiness is found with the ubiquity of the term "management". Heath $\mathrm{J}$ recently stated in $R v$ Moses: 57

Directors direct; managers manage. That is the essential difference between governance and management. Directors establish the policy or rules that are to be implemented by management and put systems in place to ensure their instructions are carried out.

53 Fatupaito $v$ Bates [2001] 3 NZLR 386 (HC).

54 At [48].

55 Lynne Taylor "Expanding the Pool of Defendant Directors in a Corporate Insolvency: De Facto Directors, Shadow Directors and Other Categories of Deemed Directors" (2010) 16 NZBLQ 203 at 220.

56 Companies Act 1993, s 128(2) (emphasis added).

$57 R v$ Moses HC Auckland CRI-2009-004-1388, 8 July 2011 at [74]. 
True as this may be, a semantic circularity does arise: while directors direct, and managers manage, if directors directly delegate their powers of management to management, these managers will be deemed directors.

What "management" must be exercised before somebody may be considered a delegated director? A fixed definition would be unworkable in the business context. The leading definition originates with Commissioner for Corporate Affairs v Bracht (Bracht) and has been approved in the New Zealand company law context. ${ }^{58}$ Ormiston J stated that: ${ }^{59}$

[T] he concept of 'management' for present purposes comprehends activities which involve policy and decision making, related to the business affairs of a corporation, affecting the corporation as a whole or a substantial part of that corporation, to the extent that the consequences of the formation of those policies or the making of those decisions may have some significant bearing on the financial standing of the corporation or the conduct of its affairs.

This was approved in Australian Securities and Investment Commission v Vines, where Austin J noted that certain responsibilities would not constitute management. These included: ${ }^{60}$

(a) "the execution of instructions by an agent whilst obeying orders";

(b) "merely administrative work of the kind performed by a company secretary or accountant (though a full examination of the facts may show that such a person ... makes management decisions)"; or

(c) "otherwise, the carrying out of day-to-day routine functions in accordance with predetermined policies".

A further issue is the level of power that must be delegated to engage s 126(1)(c). If delegated directors were required to exercise ultimate control over their delegated powers, they would be effectively identical to de facto directors. Section 126 holds de facto directors to be directors to the full extent of the Companies Act whereas delegates owe only those duties specified in s 126(1)(c).

It is possible that a liberal construction of s 126(1)(c) could encompass a senior executive in Shafron's position. He was exercising management powers as per Bracht: the separation proposal centred on policy decisions that affected the entire corporation. While he did not make the ultimate decision and the board could decline the proposal, he was fundamental to the decision made. Crafting the options available necessitates a measure of autonomy and power, sometimes even more

58 Thompson v District Court at Christchurch (2002) 9 NZCLC 262,824 (HC).

59 Commissioner for Corporate Affairs (Vic) v Bracht (1989) 14 ACLR 728 (VSC) at 733-734.

60 Australian Securities and Investments Commission v Vines [2005] NSWSC 738, (2005) 55 ACSR 617 at [1038]. 
so than that exercised by a director in assenting to an option put before them. Labelling Shafron a "delegated director" is appropriate. Even so, it remains unclear whether directors' duties will apply only to the exercise of delegated powers, or to tasks done in the wider role. ${ }^{61}$ As the Companies Act duty of care accounts for the specific office, as in the Shafron case it is likely that the court will inquire into the person's role as a whole.

\section{THE CONSEQUENCES OF BREACH}

In assessing the differences between the statutory duties in the two jurisdictions, it is vital that the enforcement regimes are taken into account. The statutory restatement of directors' duties makes enforcement more accessible to companies, but also allows the opportunity for a statutory penalty scheme.

\section{A Australia}

Australian officers' duties have more "teeth" than their New Zealand counterparts, and thus tend to be relied on more often in penalising errant corporate leaders. ASIC has the power to directly enforce officers' duties in all circumstances, ${ }^{62}$ whereas New Zealand's FMA can only enforce duties owed by "financial markets participants". ${ }^{63}$ The duties are civil obligations and any breach will qualify for a declaration of contravention. ${ }^{64}$ Once a declaration has been made, ASIC may apply for a pecuniary penalty order to a maximum of AUD200,000 for an individual, ${ }^{65}$ and/or to have the person disqualified from managing corporations. ${ }^{66}$ Compensation may also be awarded to the corporation, whether or not a declaration of contravention is made. ${ }^{67}$ As in New Zealand, companies themselves enforce the common law and equitable duties. ${ }^{6}$

Those who are not "officers" may also be involved in breaching civil penalty provisions, if "involved in the contravention" of one of these officers' duties - for example, by aiding, abetting, counselling or procuring the contravention. ${ }^{69}$ However, it must be proven that the person had

\footnotetext{
61 Taylor, above n 55, at 221.

62 Corporations Act 2001 (Cth), s 1317J.

63 Financial Markets Authority Act 2011, s 9(1)(c).

64 Corporations Act 2001 (Cth), s 1317E.

65 Section $1317 \mathrm{G}$.

66 Section 206C.

67 Section $1317 \mathrm{H}$.

68 Ministry of Economic Development, above n 3, at 183.

69 Corporations Act 2001 (Cth), s 79.
} 
knowledge of the essential elements of the contravention (although they need not be aware that the matters constituted a contravention). ${ }^{70}$ This narrows the scope of potential accessory liability.

The breach of certain officers' duties is also criminalised. Section 184(1) criminalises the failure to act in good faith in the best interests of the corporation, or for a proper purpose, when done recklessly or with intentional dishonesty. Sections 184(2) and 184(3) criminalise the use of position, or information gained through their position, to intentionally or recklessly benefit themselves or others. Notably, ss 184(2) and (3) apply not only to officers but to all employees.

Looking at recent litigation against company directors and officers, several commentators have noted ASIC's tendency to pursue actions for breach of core duties, rather than accessorial liability for more specific offences within the Corporations Act. ${ }^{71}$ Herzberg and Anderson describe this as a "stepping stone" approach, whereby the company's contravention leads to a finding that in "exposing their company to the risk of criminal prosecution, civil liability or significant reputational damage, directors contravened one or more of their statutory duties". ${ }^{72}$

This was how Shafron was found liable. Herzberg and Anderson think this a practical approach - liability is imposed only where an officer's involvement amounts to a breach of their personal duties. However, Bednall and Ngomba believe it may result in unduly harsh consequences. The knowledge requirements for accessorial liability will not be necessary for officers to be found liable for "failure to prevent a corporate contravention". ${ }^{73}$ Therefore, "officers" may be liable where the requirements for accessorial liability are not met. Bednall and Ngomba dislike the fact this creates a "harsher standard for company officers compared to the rest of the community", where the officers may not be decision-makers. ${ }^{74}$ This critiques not only the "stepping stone" approach, but the application of duties to officers in general. Such duties exist to hold this class of person to a higher standard, due to their central role in the company.

70 Yorke v Lucas (1985) 158 CLR 661 (HCA) at 667.

71 Abe Herzberg and Helen Anderson "Stepping Stones - From Corporate Fault to Directors' Personal Civil Liability" (2012) 40 FLR 181; Tim Bednall and Victoria Ngomba "The High Court and the C-Suite: implications of Shafron for company executives below board level" (2013) 31 C\&SLJ 6.

72 Herzberg and Anderson, above n 71, at 181 .

73 Bednall and Ngomba, above n 71, at 20.

74 At 20 . 


\section{B New Zealand}

Directors' duties are not enforced in New Zealand to the same extent. The securities law reforms of 2013-2014 seek to address the enforcement of directors' duties, ${ }^{75}$ however even with these new measures, any direct enforcement will still be more limited than its Australian counterpart. First, only duties owed by directors of "financial markets participants" may be publicly enforced. Secondly, there are no civil pecuniary penalties available to sanction bad behaviour.

The scheme of the Companies Act primarily envisages the private enforcement of directors' duties. If a breach is proven, several remedies are available:

(a) Upon an application by a liquidator, creditor or shareholder, the court may order: ${ }^{76}$

(i) repayment or restoration of money or property with interest; or

(ii) compensation as the court sees fit.

(b) The court may order an injunction to prevent a future breach and order any consequential relief. ${ }^{77}$

(c) The court may disqualify directors from taking part in company management for a maximum period of 10 years. ${ }^{78}$ In certain instances, the Registrar or the FMA may also ban directors from management. ${ }^{79}$

Directors' duties are owed to the company. Therefore, the majority of cases are brought by a liquidator seeking to have errant directors return funds to the company. If the company is solvent and the directors in breach remain in control, it is highly unlikely that an action will be brought against a fellow director. It is possible that a shareholder or director will be granted leave to bring an action on the company's behalf under s 165, but there is usually little incentive for derivative action when the potential reward is weighed against the cost of litigation. Shareholders stand to gain little, as any compensation will be payable to the company. ${ }^{80}$ Group shareholder action is often too

75 Office of the Minister of Commerce Cabinet Paper to the Chair of the Cabinet Economic Growth and Infrastructure Committee: Securities Law Reform (February 2011) at [21].

76 Companies Act 1993, s 301(b)-(c).

77 Section 164

78 Section 383

79 Section 385.

80 Office of the Minister of Commerce, above n 75, at [203]. 
difficult to coordinate. ${ }^{81}$ For such reasons, private enforcement has been described as "patently inadequate". ${ }^{82}$

In recent years, there has been increasing public regulation of financial markets. Created as a consolidated market conduct regulator, the FMA has wide-ranging powers regarding "financial markets participants". Relevantly, it has the power to exercise a person's right of action against a "financial markets participant", or take over pre-existing proceedings if it is in the public interest to do so. ${ }^{83}$ Thus, the FMA has the power to bring a civil action for breach of directors' duties owed to the company under the Companies Act, but only if that company offers securities to the public.

Within the suite of company and securities law reforms, the Companies and Limited Partnerships Amendment Bill ${ }^{84}$ seeks to address (among other things) the enforcement of core directors' duties. The move to criminalise certain duties prompted a great deal of discussion. Initially, the Bill added s 138A to the Companies Act, which would have created two new offences: first, for breaching the s 131 duty to act in good faith and in the best interests of the company, if it could be shown that the director knew the conduct was "seriously detrimental to the interests of the company"; and secondly, for breaching the s 135 reckless trading provision, with knowledge that the conduct would result in "serious loss to the company's creditors". ${ }^{85}$ The maximum penalties included a \$200,000 fine and five years' imprisonment. ${ }^{86}$

This drafting provoked strong concerns, primarily that the mens rea threshold was too low to justify criminalisation. No dishonesty was required, and as a number of submissions emphasised, "seriousness" is inherently vague. The submissions to the Commerce Select Committee raised issues of overlap with existing criminal sanctions and the uncertainty and subjectivity of terms such as "best interests of the company". Rather than effectively sanctioning dishonest conduct, this section was likely to deter good directors and lead to an aversion to legitimate risk. ${ }^{87}$

81 At [203]

82 Susan Watson and Rebecca Hirsch, "Empty Heads, Pure Hearts: The Unintended Consequences of the Criminalisation of Directors' Duties" (2011) 17 NZBLQ 302 at 306.

83 Financial Markets Authority Act 2011, s 34.

84 Companies and Limited Partnerships Amendment Bill 2011 (344-2)

85 Clause 4

86 Companies and Limited Partnerships Amendment Bill 2011, cl 4; Companies Act 1993, s 373(4).

87 See for instance Institute of Directors in New Zealand Inc "Submission to the Commerce Committee on the Companies and Limited Partnerships Amendment Bill" (13 September 2012); New Zealand Law Society "Submission to the Commerce Committee on the Companies and Limited Partnerships Amendment Bill" (11 September 2012); Bell Gully, Chapman Tripp, Russell McVeagh and Simpson Grierson "Submission to 
A Supplementary Order Paper in June 2013 drastically increased the requisite mens rea. For the s 131 offence, rather than a failure to act in good faith and in the best interests of the company, the new section requires a director to act in bad faith, believing the conduct is not in the best interests of the company and knowing or being reckless as to whether such conduct will cause serious loss to the company. ${ }^{88}$ A defence was also created for directors of subsidiary companies or companies in a joint venture, in limited circumstances. ${ }^{89}$ The s 135 offence was incorporated into the existing s 380 offence for carrying on business fraudulently. The key difference is that where the original offence merely required the director's knowledge that his or her actions will result in serious loss to creditors, the amended provision requires that the loss in fact be suffered. An offence would be committed under s 380(4) when a director: ${ }^{90}$

(a) ... agrees to, or causes or allows, the business of the company to be carried on in a manner that causes serious loss to 1 or more of the company's creditors; and

(b) the director knows that a serious loss will be suffered by the company's creditors as a result of the business being carried on in that manner (whether or not the director knows the full extent of the loss or the identity of the creditors concerned); and

(c) the creditors that suffered the loss did not give their prior consent to carrying on the business in that manner.

A further Supplementary Order Paper was released in November 2013, incorporating the June amendments and creating a defence to an action brought under s 380(4). A director who "believes on reasonable grounds that all the creditors that will suffer serious loss as a result ... have been identified" and "believes that all those creditors have consented to the business being carried on in that manner" will not be liable. ${ }^{91}$ These amendments effectively remove any danger of honest directors being criminalised, but as the requisite culpability increases, it is questionable how often these provisions will be used to achieve a conviction that would not already be available under some other existing legislation.

Legislators have declined to introduce a pecuniary penalty remedy for breaching the core directors' duties. While pecuniary penalties are available for contraventions of securities legislation,

the Commerce Committee on the Companies and Limited Partnerships Amendment Bill" (7 September 2012).

88 Supplementary Order Paper 2013 (249) Companies and Limited Partnerships Amendment Bill (344-2) at 1.

89 At $1-2$

90 At $2-3$.

91 Supplementary Order Paper 2013 (403) Companies and Limited Partnerships Amendment Bill (344-2) at 3. 
some commentators have suggested that they would allow for better enforcement of directors' duties specifically, and more flexibility for judges. ${ }^{92}$ Criminal liability has a high knowledge threshold with a high burden of proof. Some directors will be sufficiently culpable to warrant pecuniary penalties even where dishonesty is not present. Compensation and disqualification may have a similar punitive effect, but compensation is calculated on damage, not culpability. Civil penalties have a lower standard of proof and could better sanction moderate wrongdoing.

It is a tough balancing act between over-involvement in private business affairs and failing to penalise those responsible for real social harm. Legislators must nurture a positive business environment and not deter boards from taking legitimate business risks. The significance of encouraging skilled, progressive directors has underscored the changes in the criminalisation provisions of the Companies and Limited Partnerships Amendment Bill. Notwithstanding the criminalisation issue, there is a clear disparity between the New Zealand and Australian enforcement of directors' duties. At present, core directors' duties are arguably under-enforced, especially where companies remain solvent.

\section{SHOULD NEW ZEALAND'S DIRECTORS' DUTIES EXTEND TO SOMEBODY IN SHAFRON'S POSITION?}

Given the uncertain scope of s 126 and the divergence between New Zealand and Australian law on this point, it is pertinent to discuss whether there is a case for amending the Companies Act to expressly extend directors' duties to those occupying senior management positions.

\section{A Other Avenues For Liability: Accessorial Liability in Relation to Issuers to the Public}

Securities legislation imposes requirements on companies issuing securities to the public such as listed companies (shares) and finance companies (debentures). A company's breach of these requirements may invoke accessorial liability for those involved. As a publicly listed entity, one element of the JHIL litigation concerned the board's misleading representation. Another element was the failure to disclose material information to the ASX. As in Australia's Corporations Act, the continuous disclosure obligations in the New Zealand Stock Exchange (NZX) Listing Rules are given legislative backing in the Securities Markets Act 1988. ${ }^{93}$ From 2006, the definition of "contravene" was widened to allow for accessorial liability. ${ }^{94}$

92 Watson and Hirsch, above n 82, at 326.

93 Securities Markets Act 1988, s 19B.

94 Securities Markets Amendment Act 2006, s 4. 
The Financial Markets Conduct Act 2013 (FMC Act), which will replace the Securities Markets Act, creates more comprehensive accessorial liability provisions. ${ }^{95}$ Breaches of pt 2 (fair dealing, including misleading representations), pt 3 (offers), pt 4 (governance) and pt 5 (market conduct, including continuous disclosure) give rise to civil liability. Those "involved in a contravention" are equally liable. ${ }^{96}$

A person is "involved in a contravention" if that person: ${ }^{97}$

(a) has aided, abetted, counselled, or procured the contravention; or

(b) has induced, whether by threats or promises or otherwise, the contravention; or

(c) has been in any way, directly or indirectly, knowingly concerned in, or party to, the contravention; or

(d) has conspired with others to effect the contravention.

The FMA may apply to the court for a declaration of contravention ${ }^{98}$ and seek a pecuniary penalty. ${ }^{99}$ For instance, for breaching the continuous disclosure obligation in s 270 , the maximum pecuniary penalty available is the largest of: (a) the consideration for the relevant transaction; (b) three times the gain made; or (c) $\$ 1,000,000$ (for an individual). ${ }^{100}$ The court may order compensation, ${ }^{101}$ and has wide powers to make additional orders. ${ }^{102}$

The Bill provides automatic accessory liability for directors. This is defined more narrowly than in s 126, as "a person occupying the position of a director of the company by whatever name called". ${ }^{103}$ Deemed directors will not fall within its scope.

95 The Securities Markets Act 1988 will be repealed on 1 December 2014 as part of the second phase of the implementation of the Financial Markets Conduct Act 2013. Parts 2, 3, 4 and 5 of the Financial Markets Conduct Act 2013 will also come into force at this time.

96 Financial Markets Conduct Act 2013, pt 8, sub-pt 3.

97 Section 533.

98 Section 486.

99 Section 489.

100 Section 385.

101 Section 494.

102 Section 498.

103 Section 6. 
On the facts of Shafron $v$ ASIC, accessory liability would likely attach to him. Secondary civil liability imports the party knowledge requirements from criminal law. ${ }^{104}$ Actual or constructive knowledge of the facts giving rise to the contravention is required. The Court found that Shafron knew disclosure was necessary and was highly involved with the DOCI. He knew of weaknesses within the reviews of the cash flow models, making them an unreliable basis for asserting that the Foundation would be "fully funded". Having failed to fully inform the board of these matters, he can certainly be said to have aided in the contravention. Sackville AJA in the sentencing judgment believed that the failure was "moulded by a desire that an important piece of market information not be disclosed". ${ }^{105}$ Shafron would be a strong candidate for accessorial liability.

\section{B Harmonisation of New Zealand and Australian Company Law}

The desire to align trans-Tasman company law may support a wider application of statutory duties. Since the Closer Economic Relations Trade Agreement in 1983, the governments have regularly recorded their goal of harmonisation of policy and regulation in business. ${ }^{106}$ Reforms, especially the FMC Act, reflect this. As ASIC continues to bring cases based in statutory duties rather than more particularised statutory contraventions, the difference has practical significance.

\section{Imposing Duties Below Board Level}

Officers' duties are well entrenched in Australian law, with suggestions that the class owing duties should be widened further. In 2006, the Corporations and Markets Advisory Committee (CAMAC) recommended that, as prior to 2000, ss 180 and 181 should be applicable to "any other person who takes part, or is concerned, in the management of the corporation". ${ }^{107}$ This would not only catch "officers" who participate in "management" (as per Bracht), but those concerned in such decisions. ${ }^{108}$ CAMAC noted the HIH Royal Commission's observations that within modern corporate structures, those below board level often make very significant decisions. Thus, it

104 Body Corporate 202254 v Taylor [2008] NZCA 317, [2009] 2 NZLR 17 at [66]; Yorke v Lucas, above n 70, at 667 .

105 Gillfillan v ASIC, above n 40, at [341].

106 Australian Government Department of Foreign Affairs and Trade "Australia-New Zealand Closer Economic Relations Trade Agreement: Memorandum of Understanding Between the Government of New Zealand and the Government of Australia on the Coordination of Business Law" (2010) $<$ www.dfat.gov.au>.

107 Australian Government Corporations and Markets Advisory Committee Corporate Duties Below Board Level: Report (April 2006) at 11.

108 At 11. The Committee considered that the provision was inadvertently narrowed when the s 9 "officer" definition was introduced. 
suggested that middle managers be subject to corporate governance standards also, notwithstanding that their actions may have "resulted from pressure from higher corporate echelons". ${ }^{109}$

The argument for imposing duties on senior management is that it would encourage the "efficient and responsible management" that the Companies Act aims for. ${ }^{110}$ It is not only directors who hold the power to materially affect shareholders' and creditors' interests.

On this basis it is difficult to justify imposing duties on non-executive directors who have only a "bird's eye view" of the company, but not the managers who see to the day-to-day running of the company. As Rogers CJ noted in AWA v Daniels: ${ }^{111}$

... many companies today are too big to be supervised and administered by a board of directors except in relation to matters of high policy. The true oversight of the activities ... resides with the corporate bureaucracy. ... It is something of an anachronism to expect non-executive directors, meeting once a month, to contribute anything much more than decisions on questions of policy and, in the case of really large corporations, only major policy. This necessarily means, that in the execution of the policy, senior management is ... exercising [the board's powers].

However, in looking at the formal role of the board in relationship to management (rather than who actually exercises managerial powers), restricting duties to directors is desirable. The board is the apex of the company. For companies issuing securities, directors are often the face and selling point of the company. The board provides the key intersection between the management and the shareholders. Thomas J's often-cited dicta articulates the relationship as follows: ${ }^{112}$

$\ldots$ it is the fundamental task of the directors to manage the business of the company. Theirs is the power and the responsibility of that management. To manage the company effectively, of course, they must necessarily delegate much of their power to executives of the company ... Although constantly referred to as "the management", the executives' powers are delegated powers, subject to the scrutiny and supervision of the directors. Responsibility to manage the company in this primary sense remains firmly with the directors.

The Companies Act imposes a management structure whereby the board is responsible for the acts of management. Unless it fulfils its monitoring function fully as per s 130, the board remains responsible for any exercise of delegated power. Furthermore, directors may only rely on

109 At 4 .

110 Companies Act 1993, long title.

111 AWA Ltd v Daniels (1992) 7 ACSR 759 (NSWCA) at 832-833.

112 Dairy Containers v NZI Bank Ltd [1995] 2 NZLR 30 (HC) at 79. 
information from a source that the director reasonably believes to be competent. Such a belief must be formed in good faith, having made proper inquiry when required. ${ }^{113}$

To discharge their duties, directors must establish internal company structures to monitor the implementation of policy. It is more appropriate for the board to regulate the management of the company. Although statutory duties may aid in this by providing a cause of action against errant managers (or a means to recover funds in a liquidation), directors should, in the writer's view, utilise contractual and extra-legal relationships (such as guidelines or policies) to uphold standards of behaviour. There are several reasons for this:

\section{Lack of clear scope}

Occupying a managerial position of sufficient significance might occur on a task-by-task basis, or a person might evolve into a managerial position over time. There is a real danger that the manager will not be aware of their potential liability. At present it is not clear what powers are exclusively directors' (and which may give rise to de facto or shadow directorship if others exercise them). The threshold for delegated directorship is even more uncertain.

\section{Dilution of directors' responsibility}

Imposing duties below board level would undermine the final responsibility of directors. Recent litigation against finance company directors has been at pains to emphasise this. ${ }^{114}$ With managers owing individual duties, directors may not monitor them quite so closely.

\section{Efficiency}

Managers may be more prone to second-guess themselves. This could impede their efficiency and result in difficulties for the board as managers become more likely to self-censor (or overreport).

\section{Practical difficulties}

The duty to act in what the person regards to be the best interests of the company would sit awkwardly when applied to both managers and directors. The term "best interests" is unclear to begin with: a multiplicity of "interests" are involved in business. Moreover, it may be inappropriate for management to determine what those interests are. Managers have prescribed roles and their access to information may be limited. Confusion could arise if the board's directions are contrary to what the manager believes to be in the best interests of the company.

113 Companies Act 1993, s 138.

114 See $R v$ Moses, above n 57; $R$ v Graham [2012] NZHC 265, [2012] NZCCLR 6; Davidson v Registrar of Companies [2011] 1 NZLR 542 (HC). 
The duty of care requires the ascertainment of what a reasonable person would do in the defendant's circumstances. Whereas directors can point to resolutions of the board, managers have fewer discrete points of decision-making. ${ }^{115}$ This may lead to evidential difficulties.

\section{Interfering with business practices}

In formulating the specific duties that each director or officer owed, the court is inquiring into company decisions with the benefit of hindsight. It is questionable whether it is appropriate for the courts to interfere with the structure of companies below the board in this manner. If directors are fulfilling their obligations correctly, it should not be necessary.

\section{Remuneration}

Managers' remuneration may not be consistent with the risks they face. Directors are paid to take on these risks.

\section{Deterrence}

Potential senior managers may be wary of taking on projects, or providing worthy advice outside their specific profession, in case they inadvertently take on statutory duties.

\section{Lack of enforceability}

It is unlikely that actions will be taken very often, although widening the scope of directors' duties would make it easier for liquidators to recover assets with which to satisfy creditors. However, s 301 already provides for errant managers who appropriate company property or act negligently.

Below criminal level, the practical effect of extending directors' duties would be minimal. A manager's duty of care is adjusted to that particular office. In practice, courts will take into account the person's liberty to exercise legitimate business judgment, although New Zealand does not codify the business judgment exception as Australia does. ${ }^{116}$ Without civil pecuniary penalties, the potential options for direct enforcement are limited. As such, the expression of duties would be primarily rhetorical, encouraging high standards within company management, rather than providing a device for enforcement.

115 Deborah A Demott "Inside the Corporate Veil: The Character and Consequences of Executives' Duties" (2006) 19 AJCL 251 at 264.

116 Farrar, above n 10, at 153. 


\section{Other avenues for recovery}

The primary public concern for corporate governance lies in the regulation of issuers of securities. With the FMC Act comes a more comprehensive accessorial liability regime. Furthermore, most senior managers with special roles will have contracts with the company, potentially imposing duties of care and skill.

\section{CONCLUSION}

Clarity and workability are paramount in ascertaining who should owe statutory duties. The definition of "director" in the Companies Act is problematic. There is authority to suggest that simply offering (non-professional) advice of a sufficiently significant nature may make a senior employee a "shadow director". ${ }^{117}$ A literal reading of s 126(1)(c) may suggest that those directly delegated any "power or duty of the board" - that is, any power of "management" - could be deemed directors too.

Section 126 focuses on the putative director's position vis-à-vis the board: above it (shadow directors), equal to it (de facto directors) or directly below it (delegated directors). Delegated directorship is especially unclear because it glosses over the fact that "management" is a matter of degree. The distinction between powers that are properly exercisable by directors (and if delegated would engage s 126(1)(c)) and those that are properly exercisable by senior management (which would not engage s 126) is nebulous. A role already blurred where executive director roles straddle the two functions, s 126(1)(c) obscures the meaning of "director" further, by applying it to those who are clearly not directors, but senior managers.

The Australian "officer" definition is consistent with a conception of "management" as a continuum: at one end, mere administration or carrying out instructions, which will not be considered management; at the other end, directors' full and final authority over business matters. Markers on such a continuum include "being concerned in" management or "participating in" management - the latter requiring a higher level of involvement. ${ }^{118}$

To avoid uncertainty, it would be best to read s 126 narrowly, as encompassing those exercising delegated powers that should be exercised by the board. The focus must be on who is exercising the actual power within the company. This encourages a system of top-down governance. While the concept of "actual power" may be somewhat artificial, where managers run the company on a dayto-day basis and non-executive directors will sit at a distance, it is the system created by wider company law. As such, even where others usurp directors' powers and are deemed directors, the de

117 Secretary of State for Trade and Industry v Deverell, above n 45.

118 See Australian Government Corporations and Markets Advisory Committee, above n 107, at 36-37. 
jure directors will not be absolved of their duties. In delegating powers (or acquiescing to others exercising their powers), directors are exercising their managerial powers. ${ }^{119}$

Imposing duties on those below board level as shadow and de facto directors is justified, as they exercise real power. However, delegated directors may not be occupying the position of, or necessarily exercising the full powers of, directors. If duties are to be imposed more broadly on senior management, s 126 is a faulty mechanism through which to do so. A functional definition, as found in the Corporations Act, would remedy the uncertainty, while retaining the flexibility necessary to encompass all companies. The point on the continuum of "management" at which those exercising powers will be subject to statutory duties must be articulated as clearly as possible. Although more a guideline than a definition, this would provide more clarity than the current provision.

That said, the practical effect of extending statutory duties to a wider class would be minimal. Senior managers of companies issuing securities will be caught by the accessorial liability regime under the FMC Act. For other companies, negligent or errant managers may be liable to compensate the company under s 301. While managers will not be criminally liable under the proposed new sections in the Companies and Limited Partnerships Amendment Bill, if they had the requisite knowledge, they could possibly be criminally liable elsewhere - for example, as a party to theft in a special relationship under s 220 of the Crimes Act 1961.

The question remains, what does this mean for somebody in Shafron's position in New Zealand, occupying the dual position of company secretary and general counsel? It is pertinent to note that in explaining the powers and duties of a company secretary in New Zealand, Chartered Secretaries New Zealand works from the assumption that the company secretary will usually owe duties as a delegated director. ${ }^{120}$ The company secretary has a far-reaching role in coordinating the board and ensuring compliance with the NZX Listing Rules where applicable. While it is not clear whether this is true, as "best practice" this assumption is certainly desirable. Possessing a dual role will be relevant in performing the duties and in formulating the standard of care required. If the general counsel role is advisory or administrative, without further involvement it is unlikely that that would be sufficient to make somebody a delegated director. Nevertheless, it is imperative that directors and those in senior management positions create clear systems of delegation, so as to eliminate as much uncertainty as possible.

119 Paul L Davies and Sarah Worthington Gower and Davies' Principles of Modern Company Law (9th ed, Sweet and Maxwell, London, 2012) at 390.

120 Chartered Secretaries New Zealand Powers and Duties of the Company Secretary (2003) at 9. 
(2014) 45 VUWLR 